\title{
Diversity and distribution of methane-oxidizing microbial communities associated with different faunal assemblages in a giant pockmark of the Gabon continental margin
}

\author{
M.A. Cambon-Bonavita ${ }^{a, 1,{ }^{*}}$, T. Nadalig ${ }^{a, b},{ }^{1,2}$, E. Roussel $^{a}$, E. Delage ${ }^{a}$, S. Duperron ${ }^{a, b, 3}$, J.C. \\ Caprais $^{b}$, A Boetius $^{c}$ and M. Sibuet ${ }^{b}$

\footnotetext{
a Ifremer Brest DEEP/LM2E-UMR 6197, BP 7029280 Plouzané, France

${ }^{\mathrm{b}}$ Ifremer Brest DEEP/LEP BP 7029280 Plouzané, France

${ }^{c}$ Max Planck Institute for Marine Microbiology, Celsius Str. 1, 28359 Bremen, Germany

${ }^{1}$ Both authors have contributed equally to the present work.

2 Present address: UMR 7156 Université de Strasbourg, Génétique Moléculaire, Génomique, Microbiologie, Strasbourg, France.

${ }^{3}$ Present address: UMR CNRS 7138, Université Pierre et Marie Curie, 7 Quai Saint Bernard, 75252 Paris Cedex 05, France.
}

*: Corresponding author : M.A. Cambon-Bonavita, email address : Marie.Anne.Cambon@iffremer.fr

\begin{abstract}
:
A giant 800-m-diameter pockmark named REGAB was discovered on the Gabon continental margin actively emitting methane at a water depth of $3200 \mathrm{~m}$. The microbial diversity in sediments from four different assemblages of chemosynthetic organisms, Mytilidae, Vesicomyidae, Siboglinidae and a bacterial mat, was investigated using comparative 16S rRNA gene sequence analysis. Aggregates of anaerobic methanotrophic archaea (ANME-2) and bacteria of the Desulfosarcina/Desulfococcus cluster were found in all four chemosynthetic habitats. Fluorescence in situ hybridization targeting the ANME-2/Desulfosarcina/Desulfococcus aggregates showed their presence few centimeters $(3-5 \mathrm{~cm})$ below the surface of sediment. 16S rRNA gene sequences from all known marine ANME groups were detected in the pockmark sediments, as well as from both known bacterial partners. The archaeal diversity was limited to the ANME cluster for all investigated samples. The bacterial diversity included members of the Proteobacteria, Bacilliales, Cytophaga/Flavobacteria, Verrucomicrobia, JS1 and Actinobacteria clusters. Bacterial 16S rRNA gene sequences related to those of known sulphideoxidizing symbionts were recovered from tissues of several invertebrates including vesicomyid clams and siboglinid tubeworms of REGAB.
\end{abstract}

Keywords: REGAB; AOM; Chemosynthetic ecosystems; Cold seep; Faunal assemblage; Microbial phylogeny 


\section{Introduction}

Deep-sea cold-seep ecosystems are characterized by high fluxes of hydrocarbons and sulphide originating from the subsurface seabed by thermogenic or microbial production. Chemotrophic microorganisms, either free-living or in symbiosis with invertebrates, are abundant at these sites where they derive energy from the oxidation of sulphide or methane (Paull et al., 1984; Sibuet et Olu, 1998; Pancost et al., 2000; Valentine et al., 2000; Orphan et al., 2001; Tunnicliffe et al, 2003). Deep-water cold seeps often show substantial accumulations of methane in the seafloor in gaseous, liquid and solid form, the latter also known as gas hydrates (Kvenvolden, 1998; Milkov and Sassen, 2002). A major fraction of the methane rising from deeper sediments to the seafloor is consumed by microorganisms within the seabed, mainly through the anaerobic oxidation of methane (Reeburgh, 1976). The anaerobic oxidation of methane (AOM) by sulphate reduction leads to the formation of sulphide and carbonate (Barnes and Goldberg, 1976 ; Reeburgh, 1976). This process is mediated by yet uncultivated methanotrophic archaea related to the methanogens, and sulphate reducers of the Deltaproteobacteria clade (Hinrichs and Boetius 2002). The sulphate-reducing bacteria (SRB) and anaerobic methanotrophic archaea (ANME) often form aggregates and occur at very high abundances in cold-seep sediments (Boetius et al., 2000; Orphan et al. 2001). Several distinct phylogenetic clusters of Archaea are involved in AOM as shown in various observations including proteomic and metagenomic data (Knittel et al. 2005, Krüger et al. 2003; Hallam et al. 2004; Meyerdierks et al., 2005). The ANME-1 group is related to the Methanosarcinales and Methanomicrobiales orders (Hinrichs et al. 1999), the ANME-2 and ANME-3 groups are related to the Methanosarcinales (Boetius et al, 2000; Niemann et al., 2006). The ANME occur in sediments in consortium with sulphate-reducing bacteria (Michaelis et al, 2005; Knittel et al, 2005) or as single cells or small assemblages (Orphan et al., 2001; Knittel et al., 2005). ANME-1 and ANME-2 are generally associated with sulphate-reducing bacteria of the Desulfosarcina/Desulfococcus cluster, and ANME-3 with the Desulfobulbus genus (Lösekann et al., 2007). The AOM process provides high fluxes of sulfide, which nourishes several types of microbe-invertebrate symbioses such as bivalves from the Lucinidae, Thyasiridae, Solemyidae and Vesicomyidae families, as well as annelid polychaetes of the family Siboglinidae (Goffredi et al., 2004 ; Duperron et al., 2007a ; Bright and Giere, 2005). Mussels from cold seeps (family Mytilidae) host methanotrophic bacteria (Cavanaugh et al., 1987; Barry et al., 2002) or live in dual symbiosis with both methanotrophic and thiotrophic bacteria (Won et al., 2003; Duperron et al., 2005; Duperron et al., 2007b). In most cold-seep environments, such chemosynthetic organisms dominate the community biomass and form specific habitats generally associated with high AOM rates. Pockmarks are a special type of cold-seep characterized by negative seafloor features caused by the seepage of fluids through the seabed (Hovland and Judd, 1988). They generally occur in unconsolidated fine-grained sediments as cone-shaped circular or elliptical depressions ranging from a few metres to 300 or more in diameter and from $1 \mathrm{~m}$ to $80 \mathrm{~m}$ in depth. The giant $800 \mathrm{~m}$ diameter pockmark REGAB was discovered along the Gabon continental margin at a water depth of $3200 \mathrm{~m}$ during the ZAIANGO cruise by geophysical surveys with the research vessel Suroit (April 2000, Ifremer). REGAB is characterized by high methane emissions and by the presence of methane hydrates in subsurface and surface sediments (Charlou et al., 2004). First dives on REGAB using the remotely operated vehicle (ROV) VICTOR 6000 (cruises ZAINGO and BIOZAIRE I - 2001) showed the occurrence of dense communities of typical seep-associated invertebrates, some of which represent chemosynthetic symbioses (Ondréas et al., 2005; Olu-Le Roy et al., 2007a). Among these were Mytilidae (Bathymodiolus aff. boomerang, Olu-Le Roy et al. 2007b), Vesicomyidae bivalves (see Cosel and Olu-Le Roy, this volume), and Siboglinidae polychaetes (Vestimentifera, Escarpia southwardae n. sp., Andersen et al., 2005). A few mats of giant sulfide oxidizing bacteria have also been observed in the pockmark. Three main faunal assemblages were observed (Figure 1): Mytilidae and Siboglinidae occur in the centre area of the pockmark associated with carbonate crusts, and Vesicomyidae mostly in 
the periphery on soft sediments. The bacterial mats patches were observed close to Vesicomyidae. Olu et al. (2007a) found that methane concentrations in the bottom water were the main factor explaining the distribution and high spatial variability of the faunal assemblages. Methane measurements in these habitats suggested that the Bathymodiolus species are exposed to highest methane concentrations while Vesicomyidae and Siboglinidae occur at the periphery of methane-emitting patches, experiencing lower methane concentrations. The occurrence of Bathymodiolus mussels in very large and dense aggregates in the most methane-rich areas is probably linked to their dual symbiosis with methane and sulphide-oxidizing Gammaproteobacteria (Duperron et al. 2005). Vesicomyidae and Siboglinidae were assumed to harbour only sulphide-oxidizers (Olu-Le Roy et al., 2007a).

In this study, we present a molecular survey of microbial communities associated with different types of habitats in the REGAB giant pockmark. The two main goals were to assess microbial diversity associated with the different faunal assemblages including their bacterial symbionts, and to assess the distribution of microorganisms involved in AOM in the seafloor.

\section{Material and methods}

\subsection{Sample collections}

During the BIOZAIRE II cruise in November 2001, aboard the research vessel L'Atalante, sediment samples were collected with push cores operated by the ROV VICTOR 6000 (Figure 1). The target sites in the REGAB pockmark at $3152 \mathrm{~m}$ depth included sites M2 and M3 close to Mytilidae (dives 146 and 147, cores CT15 and CT2 respectively), sites V1 and V3 close to Vesicomyidae (dives 145 and 147, cores CT1 and CT8 respectively), site Vest close to Siboglinidae (dive 146, core CT4) and site "Mat" on bacterial mat (dive 146, core CT10) (Table 1). Lengths of sediment cores were $15 \mathrm{~cm}$ except for $M 2$, V3 and Vest sites because of carbonate concretions below 8,10 and $10 \mathrm{~cm}$ sediment depth, respectively. The site nomenclature follows the one that had been used before (Olu-Le Roy et al., 2007a; Duperron et al., 2007). Description of the faunal communities associated with the sites can be found in Olu-Le Roy et al., 2007a. Siboglinidae, Mytilidae and Vesicomyidae were collected by the ROV grab and rapidly dissected on board. Bivalve gills and siboglinid trophosomes were frozen for phylogenetic analysis of bacterial symbionts.

\subsection{Methane concentration measurement}

Fluids were sampled using the water sampling pump and collected in $200 \mathrm{ml}$ titanium bottles at the different sites (Table 1). Methane concentrations were measured as described previously (Olu et al., 2007a).

\subsection{Fluorescence in situ hybridization (FISH)}

Subsamples of sediment cores were sliced into $1 \mathrm{~cm}$ intervals and fixed for $2 \mathrm{~h}$ with $2 \%$ formaldehyde solution. After washing with PBS (10 mM sodium phosphate, $130 \mathrm{mM} \mathrm{NaCl}$ ), samples were stored in PBS/ethanol $(1 / 1)$ at $-20^{\circ} \mathrm{C}$ until used in the laboratory. Fixed sediment samples were diluted ten times in PBS/ethanol and sonicated 20 s. Twenty $\mu \mathrm{L}$ were filtered on $0.2 \mu \mathrm{m}$ GTTP polycarbonate filters. Separated hybridizations with two monolabelled probes were done on half cut filters. Microbial aggregates were counted after hybridization with Cy3 monolabelled probes, probe EelMS932 (5'AGCTCCACCCGTTGTAGT-3') for archaea ANME-2 and probe DSS658 (5'TCCACTTCCСТСТСCCAT-3') for sulfate-reducing bacteria (Desulfosarcina /Desulfococcus). After staining with 4,6-diamidino-2-phenylindole (DAPI), aggregates were counted with the appropriate fluorescent filters on a Olympus $\mathrm{BH}-2$ microscope. For each 
sample slide, 500 microscope fields were counted and reported as number of aggregates per $\mathrm{ml}$.

\subsection{DNA extraction}

DNA from the different samples ( $0.8 \mathrm{~g}$ per sample) was extracted with FastDNA SPIN kit for soil (Bio 101 System, Qbiogen) with the modifications previously described by Webster et al. (2003). The DNA extraction and amplification procedures gave good results on all samples except the bacterial mat sample. Therefore, the DNA extraction of the bacterial mat sample (dive 146 core CT10) was carried out on $5 \times 0.8 \mathrm{~g}$ replicates. The replicates were pooled, concentrated and purified with YM-100 centrifugal filters (Millipore Corporation) to give a final volume of $70 \mu \mathrm{L}$.

\subsection{PCR and cloning}

For cores CT1 and CT2, amplifications were performed using the 16S rRNA gene universal primers for Bacteria or Archaea: U1492r (5'-GTT ACC TTG TTA CGA CTT-3') as reverse universal primer, E8f (5'-AGA GTT TGA TCA TGG CTC AG-3') for Bacteria and A8f (5'-CGG TGG ATC CTG CCG GA-3') for Archaea. The amplifications for cores CT4, CT8, CT15 and Bacteria in core CT10 were performed with: U1407r (5'-GAC GGG CGG TGW GTR CAA-3') as reverse universal primer, E338f (5'-ACT CCT ACG GGA GGC AGC-3') for Bacteria and E344f (5'-AYG GGG YGC ASC AGG SG-3') for Archaea.

For amplification of Archaea in core CT10, nested PCR was conducted with combination of 16S rRNA gene primers for Archaea with 8f (5'-CGG TTG ATC CTG CCG GA-3') and 1492r (5'-GGC TAC CTT GTT ACG ACT T-3') in the first round, with 344f (5'-AYG GGG YGC ASC AGG SG-3') and 915r (5'-GTG CTC CCC CGC CAA TTC CT-3') in the second round. Five independent PCR products from the first round were pooled and purified (QIAquick PCR purification Kit, Qiagen) and used as a template for the second PCR round.

The bulk DNA was amplified in a $50 \mu \mathrm{l}$ reaction mix containing (final concentration): 1X Taq DNA polymerase buffer (Q biogen, Strasbourg, France), $20 \mu \mathrm{M}$ of each dNTP, $20 \mu \mathrm{M}$ of each primer and $0.5 \mu \mathrm{l}$ of Taq DNA polymerase (Q Biogen, Strasbourg, France). Reaction mixtures were held at $94^{\circ} \mathrm{C}$ for 3 min followed by 30 cycles of $94^{\circ} \mathrm{C}$ for $60 \mathrm{~s}, 49^{\circ} \mathrm{C}$ (except for primer couples U1407r-E338f, A1492r-A344f and A915r-A344f: $54^{\circ} \mathrm{C}, 55^{\circ} \mathrm{C}$ and $57^{\circ} \mathrm{C}$ respectively) for $90 \mathrm{~s}$ and $72{ }^{\circ} \mathrm{C}$ for $120 \mathrm{~s}$, with a final extension step of $6 \mathrm{~min}$ at $72{ }^{\circ} \mathrm{C}$. PCR products were then visualized on a ethidium bromide containing agarose gel before cloning. Before cloning, two to four PCR products were pooled, purified and concentrated using the QIAquick PCR purification kit (Quiagen SA, Grenoble, France) following the manufacturer's instructions. Clone libraries were constructed by transforming E. coli TOP10F'using the TOPO TA Cloning kit (Invitrogen Corp., San Diego CA USA) according to the manufacturer's protocol. Clones harbouring the expected insert were then cultured and treated for sequencing on the "Ouest Genopole Plateform" (Roscoff, France, http//www.sbroscoff.fr/SG/) on a Abi prism $3100 \mathrm{GA}$ (Applied Biosystem), using the big-Dye Terminator V3.1 (Applied Biosystem) following the manufacturer's instructions.

\subsection{Phylogenetic analyses}

To determine preliminary phylogenetic affiliations, sequences were compared to those available in databases using the BLAST network service (Altschul et al., 1990). Alignments of 16S rRNA gene sequences were performed using CLUSTALW (Thompson et al., 1994), further refined manually using SEAVIEW (Galtier et al., 1996). The trees were constructed by PHYLO-WIN (Galtier et al., 1996). Only homologous positions were included in the phylogenetic comparisons. For the 16S rRNA phylogenetic reconstruction, the robustness of inferred topology was tested by bootstrap resampling (1000) (Felsentein, 1985) of the tree calculated on the basis of evolutionary distance (neighbour-joining algorithm with Kimura 2 correction). For the Gamma and and Deltaproteobacteria phylogenetic reconstruction, the 
Maximum Likelihood was used with 100 bootstraps resampling. Sequences displaying more than $97 \%$ similarity were considered to be related, and grouped in the same phylotype.

\subsection{Nucleotide sequence accession numbers.}

Sequences have been deposited at EMBL for partial 16S rRNA gene sequences. The clones were named according to the sample core number (CTi), and A for Archaea and B for Bacteria. For the symbionts, the entire name of the host was used. The accession numbers are AM888202 to AM888272.

\section{Results and discussion}

\subsection{Distribution of AOM consortia}

Fluorescence in situ hybridization of pockmark sediments showed abundant microbial aggregates targeted with ANME-2 and DSS probes. All the counted aggregates were also visualized with DAPI staining. The aggregates consisted of ANME-2 archaea surrounded by sulphate-reducing bacteria of the Desulfosarcina/Desulfococcus cluster (Figure 2). No monospecies aggregates of ANME-2 were found as previously detected in cold seep sediments from Eel River Basin (Orphan et al., 2002). Depth profiles of the number of AOM consortia differed between the habitats (Figure 3). Sediment from the Mytilidae site M3 contained the highest number of aggregates $\left(1.8 \times 10^{7} \mathrm{~cm}^{-2}\right)$ integrated over $15 \mathrm{~cm}$ depth. This was twice as much as at the Vesicomyidae site V1 $\left(0.99 \times 10^{7} \mathrm{~cm}^{-2}\right)$ and ten times more than at the microbial mat site $\left(0.16 \times 10^{7} \mathrm{~cm}^{-2}\right)$. At all sites except the Vest site the surface sediments did not contain aggregates. The reason could be the depletion of methane in the surface layers and/or the oxygenation of the surface sediments. The maximum of aggregate counts in sediments from the microbial mat site occurred between 5 and $6 \mathrm{~cm}\left(7 \times 10^{5} \mathrm{~cm}^{-3}\right)$ and between 10 and $11 \mathrm{~cm}$ for the Vesicomyidae site $\left(30 \times 10^{5} \mathrm{~cm}^{-3}\right)$. The density of aggregates for the Mytilidae sites (M2 and M3) showed a maximum between 13 and $14 \mathrm{~cm}$ $\left(28 \times 10^{5} \mathrm{~cm}^{-3}\right)$. At the microbial mat site, aggregates were restricted to the uppermost centimetres (between 3 and $8 \mathrm{~cm}$ ) whereas at all other sites the aggregate numbers did not decrease with depth. We assume that the bioturbation by the bivalves and hence oxygenation in surface and greater availability of sulfate in subsurface sediments, can explain the deeper distribution of aggregates in $\mathrm{M} 3$ and V1 sites compared to the bacterial mat site. Distribution of aggregates in sediments below siboglinid tubeworms (Vest site) showed no trend with sediment depth. Aggregates were detected in the first ten centimetres of sediment. Tubeworms use their roots to take up hydrogen sulphide, which fuels the thiotrophic symbiotic bacteria in their trophosome (Julian et al., 1999; Freytag et al., 2001). Then the tubeworms release sulfate across their roots into the surrounding sediments (Dattagupta et al., 2008), probably creating variable microhabitats for the AOM consortia. .Moreover, Vestimentiferan tubeworm assemblages are usually associated with reduced sediments where oxygen is rapidly consumed in the first centimetres (Ritt, Sarrazin et al. in prep).

The densities of microbial aggregates in the pockmark sediments follow the same trend as the methane concentrations in the bottom waters, which were much higher at M3 $(23.5 \mu \mathrm{M})$ than at $\mathrm{V} 1(0.9 \mu \mathrm{M})($ Table 1$)$. Probably bottom water concentrations are linked to the gradient in total methane fluxes from the seafloor to the hydrosphere, decreasing from the mussel sites to the bacterial mats. 


\subsection{Symbiont sequences}

Invertebrate communities at REGAB are dominated by taxa previously reported to harbour chemosynthetic bacterial symbionts, including Mytilidae, Vesicomyidae and Siboglinidae (Fisher 1990). Specimen of the mytilid Bathymodiolus sp. from the Gabon margin were investigated previously and shown to harbour two phylotypes related to sulphide- and methane-oxidizing symbionts (Duperron et al., 2005). No evidence for methane-oxidizing symbionts was found in the bacterial clone libraries from the two invertebrate species investigated here (Figure 6). A single phylotype, related to the sulphide-oxidizing endosymbiont of Calyptogena pacifica was recovered from the vesicomyid clam. Vesicomyid clams are known to harbour chemoautotrophic symbionts and to colonize sulphide-rich habitats at vents and seeps (Peek et al., 1998). Symbiosis in the tubeworm was also investigated, and preliminary results based on electron micrographs suggested the presence of sulphide-oxidizing symbionts (Andersen et al., 2005) confirmed by the sequence obtained here. Although FISH was not performed on animal samples, the close relationship between sequences recovered and known symbionts suggests that these sequences represent the dominant symbionts, although the presence of additional symbionts remains to be addressed in more specific studies. Symbiosis is known to be of prime importance in the productivity of cold seep communities (Sibuet and Olu, 1998), and recent results confirm that availability of energy in the form of methane and sulfide to the symbiosis is a key parameter for distribution and structure of communities at REGAB (Duperron et al., 2005, Olu et al., 2007a).

\subsection{Evidence of AOM in REGAB pockmark through molecular survey}

DNA was extracted, according to FISH results, from each sample where the AOM consortia were most abundant (Table 1). As the present study was mainly focused on the identification of the microorganisms involved in AOM in the seafloor, only a limited number of clones were sequenced. For the CT10 sample from the thiotrophic mat, the use of nested PCR was necessary to obtain a correct amplification of the archaeal 16S rRNA genes, confirming the low abundance of Archaea in this sample. From the Mat sample, we sequenced 78 clones from the bacterial library and 39 from the archaeal one. For each other sediment sample, 25 to 30 clones were sequenced both for Archaea and Bacteria. 18 to 20 sequences were suitable to be used for phylogenetic analyses, the others 10 being too short for proper phylogenetic analysis.

\subsubsection{Archaeal diversity}

In all samples, the archaeal diversity comprise only members of the ANME-1b, ANME-2 ( $a, b$ and c) and ANME-3 clusters (Table 2 and Figure 4). For the CT10 sample from the thiotrophic mat, nearly half of the sequences obtained were related to ANME-2a and formed two clusters closely associated to uncultured Methanosarcinales (> 98\% similarity) and to clones retrieved at Kazan mud volcano (ANME-2ab). The other sequences are related to the ANME-3 group, forming a cluster closely related to environmental sequences from methanerich sites such as Eel River Basin. The seawater overlying the mytilid sites M2 and M3 displayed the highest methane concentration (Table 1), corresponding to higher densities of aggregates in the seafloor. As encountered in other studies, few archaeal sequences were retrieved (Inagaki et al., 2004) despite the high abundance of aggregates according to FISH results (this study, Lösekann et al., 2007). All archaeal sequences were affiliated to the ANME-2C and ANME-3 groups. For the Vesicomydae and Siboglinidae fields, few archaeal sequences were retrieved and these were also all affiliated to ANME clusters.

This relative low archaeal diversity is to be compared to other methane rich environments such as Kazan mud volcano (Heijs et al., 2007), Haakon Mosby mud volcano (Niemann et al., 2006), Black-Sea (Treude et al., 2005, Knittel et al., 2005), Hydrate Ridge (Knittel et al., 2005), Eel River basin (Orphan et al., 2001), Ryukyu Arc seeps (Inagaki et al., 2004) and Gulf of Mexico (Lloyd et al., 2006). In all these methane-rich environments, archaeal diversity is clearly dominated by ANME members but in most of these sites, sequences related to 
other Euryarcheota (e.g. Thermoplasmales) or Crenarcheota (marine benthic group B, C) were also found, which is not the case here (Knittel et al. 2005). However, this apparently low diversity may also be related to the low number of sequences analysed for this preliminary study.

\subsubsection{Bacterial diversity}

The bacterial diversity is apparently higher than the archaeal one (Table 2 and Figure 5 and 6 ), as described for the other environments cited above. Nevertheless, the sequences obtained for each sample are all affiliated to a small number of phylogenetic groups.

Twenty six sequences were affiliated to the Epsilonproteobacteria cluster (Figure 5), most of them being closely related to sequences retrieved from deep-sea sediments (NKB sequences) and to methane-rich environments. Some sequences are related to environmental clones associated to chemosynthetic deep-sea marine invertebrates and could thus represents sulfur oxydizers.

Few sequences (CT10 and CT2) were related to the Alphaproteobacteria, AgrobacteriumHalophaga division ( $>98 \%$ similarity), showing similar results to those reported from Kazan Mud volcano (Heijs et al., 2007) and Eel River basin (Orphan et al., 2001). This group, closely related to Hyphomicrobium sequences, could represent aerobic methylotroph species.

Fourteen sequences were related to the Gammaproteobacteria and three of them were related to mytilid-associated methanotrophic endosymbiont sequences (>98\%). This result could suggest the occurrence of free-living, close relatives of mussel symbionts in the environment. A more general survey of methanotrophs is needed, including a complete phylogenetic analysis of the first centimetres where lipid signatures indicate the presence of aerobic methanotrophs (Bouloubassi pers. com.).

Relatives of the Deltaproteobacteria dominated the bacterial clone libraries with 42 sequences (Figure 6). Most of the clones were related to the DSS subgroup (Desulfosarcina/Desulfococcus relatives) to which the bacterial partners in AOM belong. Some sequences were closely related to the DBB subdivision (Desulfobulbus relatives), which also includes bacteria involved in AOM associated with members of the ANME3 archaeal group (Niemann et al., 2006).

Other clones were related to clusters usually encountered in deep-sea sediments such as Bacilliales (8 clones), Verrucomicrobiales (7 clones), Green non sulphur (16 clones), Actinobacteria (21 clones), and the Cytophaga - Flexibacter - Bacteroidetes (CFB) (19 clones). These clusters are generally supposed to be heterotrophic and present quite versatile groups found in many environments (Alain et al., 2002). In the present study, our clone sequences are mostly related to environmental sequences originated from methane and hydrocarbon-rich areas (Kazan mud volcano, Golf of Mexico or Guaymas Basin).

Members of the JS1 group (8 clones) were also retrieved under the mat sample and from the mytilid field. Representative sequences of the JS1 group have previously been found in methane-rich subsurface sediments where gas hydrates are present (Webster et al., 2004). This suggests that some members of the JS1 division may be associated with methanogenic consortia. JS1inhabit strictly anoxic organic-rich environments (Webster et al., 2006).

Results from this preliminary study clearly indicate that key microorganisms mediating the anaerobic oxidation of methane occur below each type of faunal assemblage (thiotrophic mat, Mytilidae, Vesicomyidae) on the REGAB pockmark. Too few sequences were recovered from the Siboglinidae fields to draw any conclusion, but these preliminary results seem to confirm also the presence of AOM consortia under the Siboglinidae fields. Interestingly, all known marine AOM-mediating groups were present in clone libraries of the pockmark sediments. Below the Bathymodiolus field, aggregates were most abundant but the archaeal PCR amplification yielded poor results. The low number of ANME-related sequences in sediments characterized by high methane concentration such as observed here was previously reported (Inagaki et al., 2004, Lösekann et al., 2007) and could be due to PCR inhibition or biases (Lösekann et al., 2007). In the absence of quantitative data regarding 
abundances, the relative importance of each group cannot be assessed. Nevertheless, the occurrence of strongly ${ }^{13} \mathrm{C}$-depleted archaeal lipids (such as archaeol, sn-2 hydroxyarchaeol, crocetane and PMI), clearly points out to substantial biomass of anaerobic methanotrophic archaea (Bouloubassi, this volume). Their composition and relative abundance indicate a methanotrophic archaeal community dominated by ANME-2 members. In addition, the cooccurrence of ${ }^{13} \mathrm{C}$-depleted monoalkyl glycerol ethers (MAGE) indicates the presence of sulphate reducing bacteria among the Desulfosarcinales group, also implicated in AOM with ANME-2. The downcore distribution of archaeal and bacterial (SRB) lipids provides evidence for dominant anaerobic oxidation of methane (AOM) and concomitant sulphate reduction below the upper $2 \mathrm{~cm}$ layer of the sediments (Bouloubassi pers. comm.). Within the surface sediment layer, AOM-related biomarkers show low concentrations, whereas, in contrast, amounts of ${ }^{13-} \mathrm{C}$ depleted diploptene are highest, most likely reflecting aerobic methanotrophy in the zone where oxygen penetrates from the overlying bottom water (Bouloubassi this volume).

\section{Conclusion}

The sediments collected from four main types of chemosynthetic habitats of the REGAB pockmark, characterized by aggregations of Mytilidae, Vesicomyidae, Siboglinidae and thiotrophic bacterial mats, have been found to contain abundant AOM consortia. The ANME-2/DSS shell-type aggregates were concentrated a few centimetres below the surface $(3-5 \mathrm{~cm})$. Highest densities of AOM consortia were discovered at the Mytilidae sites, which also showed the highest methane concentrations in the bottom waters.

Due to the necessary use of 30 PCR cycles, and the investigation of limited numbers of clones, we were not able to give an exhaustive description of the diversity of microbial communities present on the REGAB site. Nevertheless, representatives of all ANME groups were found at REGAB, comprising all recovered archaeal sequences. Bacterial diversity in clone libraries from the REGAB sediment was relatively high for the number of clones examined and included sequences related to aerobic methanotrophs, sulphide oxidizing and sulphate reducing bacteria, as well as diverse heterotrophs. The bacterial 16S rRNA genes associated with the 3 main types of chemosynthetic invertebrate symbioses of mytilids, vesicomyids and siboglinids were closely related to known thiotrophic symbionts of the respective groups. Only the mytilids contained a second symbiont related to aerobic methanotrophs. This indicates that the rich chemosynthetic communities of the REGAB pockmark are mostly dependent on $\mathrm{AOM}$ as the sulphide generating process in this ecosystem.

\section{References}

Alain K., Olagnon, M., Desbruyères, D., Page, A., Barbier, G. , Juniper, K. , Quérellou J. and Cambon-Bonavita. M.A. 2002. Phylogenetic characterization of the bacterial assemblage associated with the hydrothermal vent polychaete Paralvinella palmiformis. FEMS Microbiology Ecology 42 463-476 .

Altschul S., Gish W., Miller W., Myers E., Lipman D., 1990. Basic local alignment search tool. Journal of Molecular Biology 215, 403-410.

Andersen A.C., Hourdez S., Marie B., Jollivet D., Lallier F.H., Sibuet M., 2005. Escarpia southwardae sp. nov., a new species of vestimentifera tubeworm (Annelida, Siboglinidae) from West African cold seeps. Canadian Journal of Zoology 82, 980-999. 
Barnes R.O., Goldberg E.D., 1976. Methane production and consumption in anoxic marine sediments. Geology 4, 297-300.

Barry J.P., Buck K.R., Kochevar R.K., Nelson D.C., Fujiwara Y., Goffredi S.K., Hashimoto J., 2002. Methane-based symbiosis in a mussel, Bathymodiolus platifrons, from cold seeps in Sagami Bay, Japan. Invertebrate Biology 121, 47-54.

Boetius, A., Ravenschlag K., Schubert C.J., Rickert D., Widdel F., Gieseke A., Amann R., Jorgensen B.B., Witte U., Pfannkuche O., 2000. A marine microbial consortium apparently mediating anaerobic oxidation of methane. Nature 407, 623-626.

Bright M., Giere O., 2005. Microbial symbiosis in Annelida. Symbiosis 38, 1-45.

Cavanaugh C.M., Levering, P.R., Maki J.S., Mitchell R. and Lidstrom M.E.,1987 Symbiosis of methylotrophic bacteria and deep-sea mussels. Nature 325, 346-347.

Charlou J.L., Donval J.P., Fouquet Y., Ondreas H., Knoery J., Cochonat P., Levache D., Poirier Y., Jean-Baptiste P., Fourre E., 2004. Physical and chemical characterization of gas hydrates and associated methane plumes in the Congo-Angola Basin. Chemical Geology 205, 405-425.

Dattagupta S., Arthur M.A. and Fisher C.R. 2008. Modification of sediment geochemistry by the hydrocarbon seep tubeworm Lamellibrachia luymesi : a combined empirical and modelling approach. Geochimica et Cosmochimica Acta 72, 2298-2315.

Duperron S., Nadalig T., Caprais J.C., Sibuet M., Fiala-Medioni A., Amann R., Dubilier N., 2005. Dual symbiosis in a Bathymodiolus sp. mussel from a methane seep on the gabon continental margin (southeast Atlantic): 16S rRNA phylogeny and distribution of the symbionts in gills. Applied and Environmental Microbiology 71, 1694-1700.

Duperron S., Fiala-Medioni A, Caprais J.C., Olu K., Sibuet M., 2007a. Evidence for chemoautotrophic symbiosis in a Mediterranean cold seep clam (Bivalvia : Lucinidae): comparative sequence analysis of bacterial $16 \mathrm{~S}$ rRNA, APS reductase and RubisCO genes. FEMS Microbiology Ecology 59, 64-70.

Duperron S., Sibuet M., MacGregor B.J., Kuypers M.M.M., Fisher C.R., Dubilier N., 2007b. Diversity, relative abundance and metabolic potential of bacterial endosymbionts in three Bathymodiolus mussel species from cold seeps in the Gulf of Mexico. Environmental Microbiology 9, 1423-143

Felsentein J., 1985 Confidence limits on phylogenies: an approach using the bootstrap. Evolution 30: 783-791.

Fisher C. R., 1990. Chemoautotrophic and methanotrophic symbioses in marine invertebrates. Reviews in Aquatic Sciences 2, 399-613.

Freytag J.K., Girguis P.R., Bergquist D.C., Andras J.P., Childress J.J., Fisher C.R., 2001. A paradox resolved: sulfide acquisition by roots of seep tubeworms sustains net chemoautotrophy. Proceedings of the national academy of sciences 98, 13408-13413.

Galtier N., Gouy M. and Gautier C. 1996 SEAVIEW and PHYLO_WIN: two graphic tools for sequence alignment and molecular phylogeny. Computer Applications in the Biosciences, 12: $543-548$. 
Goffredi S.K., Barry J.P., Buck K.R., 2004. Vesicomyid symbioses from Monterey Bay (Central California) cold seeps. Symbiosis 36, 1-27.

Hallam SJ, Putnam N, Preston CM, Detter JC, Rokhsar D, Richardson PM, DeLong EF. 2004. Reverse methanogenesis: testing the hypothesis with environmental genomics. Science. 2004 Sep 3;305:1457-62.

Heijs S.K., Haese R.R., Van der Wielen P.W., Forney L.J. , Van Elsas J.D., 2007. Use of $16 \mathrm{~S}$ rRNA gene based clone libraries to assess microbial communities potentially involved in anaerobic methane oxidation in a Mediterranean cold seep. Microbial Ecology 53, 384-398.

Hinrichs K.U., Hayes J.M., Sylva J.M., Brewer P.G., Delong E.F., 1999. Methane-consuming archaebacteria in marine sediments. Nature 398, 802-805.

Hinrichs K.U.and Boetius A. 2002 in Ocean Margin Systems (Eds Wefer G. et al.) 457-477 Springer Verlag, Berlin.

Hovland, M., Judd, J., 1988. Seabed Pockmarks and Seepages: Impact on Geology, Biology and Marine Environment vol. 293. Graham and Trotman, London, pp. 65.

Inagaki F., Tsunogai U., Suzuki M., Kosaka A., Machiyama H., Takai K., Nunoura T., Nealson K. , Horikoshi K., 2004. Characterization of C1-metabolizing prokaryotic communities in methane seep habitats at the kuroshima knoll, southern Ryukyu arc, by analysing pmoA, mmoA, mcrA and 16S rRNA genes. Applied and Environmental Microbiology 70, 7445-7455.

Julian D., Gaill F., Wood E., Arp A.J., Fisher C.R., 1999. Roots as a site of hydrogen sulfide uptake in the hydrocarbon seep vestimentiferan Lamellibrachia $\mathrm{sp}$. The Journal of Experimental Biology 202, 2245-2257.

Knittel K., Lösekann T., Boetius A., Kort R., Amann R., 2005. Diversity and distribution of methanotrophic archaea at cold seep. Applied and Environmental Microbiology 7, 467-479.

Kruger M., Meyerdierks A., Glockner F.O., Amann R., Widdel F., Kube M., Reinhardt R., Kahnt J., Bocher R., Thauer R.K., Shima S. 2003. A conspicuous nickel protein in microbial mats that oxidize methane anaerobicallyNature. Dec 18;426:878-81.

Kvenvolden K.A., 1998. Methane hydrate and global climate. Global Biogeochemical Cycles 2, 221-229.

Lösekann T., Knittel K., Nadalig T., Fuchs B., Niemann H., Boetius A., Amann R., 2007. Diversity and abundance of aerobic and anaerobic methane oxidizers at the Haakon Mosby Mud Volcano, Barents Sea. Applied and Environmental Microbiology 73, 3348-3362

Lloyd K.G., Lapham L. , Teske A., 2006. An anaerobic methane oxidizing community of ANME-1b Archaea in hypersaline gulf of Mexico sediments. Applied and Environmental Microbiology 72, 7218-7230.

Meyerdierks, A., Kube M., Lombardot T., Bauer M., Glöckner F.O., Reinhardt R. and Amann R., 2005. Insights into the genomes of archaea mediating anaerobic oxidation of methane. Environmental Microbiology 7 , 1937-1951.

Michaelis W., Seifert R., Nauhaus K., Truede T., Thiel V., Blumenberg M., Knittel K., Gieseke A., Peterknecht K., Pape T., Boetius A., Amann R., Jorgensen B.B., Widdel F., Peckmann J., 
Pimenov N.V., Gulin M.B., 2002. Microbial reefs in the Black Sea fueled by anaerobic oxidation of methane. Science 29, 1013-1015.

Milkov A.V., Sassen R., 2002. Economic geology of offshore gas hydrate accumulations and provinces. Marine and Petroleum Geology 19, 1-11.

Niemann H., Lösekann T., de Beer D., Elvert M., Nadalig T., Knittel K., Amann R., Sauter E.J., Schlüter M., Klages M., Foucher J.P., Boetius A., 2006. Novel microbial communities of the Haakon Mosby mud volcano and their role as a methane sink. Nature 443, 854-858.

Olu-Le Roy K. Caprais J.C., Fifis A., Fabri M.C., Galeron J., Budzinsky H., Le Menach K., Khripounoff A., Ondreas H., Sibuet M., 2007a. Cold-seep assemblages on a giant pockmark off West Africa: spatial patterns and environmental control. Marine Ecology-An Evolutionary Perspective 28, 115-130.

Olu-Le Roy K, Von Cosel R., Hourdez S., Carney S.L., Jollivet D. 2007b. Amphi-Atlantic cold-seep Bathymodiolus species complexes across the Equatorial belt. Deep-Sea Research Part I. Oceanographic Research Papers 54 (11), 1890-1911.

Ondréas H., Olu K., Fouquet Y., Charlou J.L., Gay A., Dennielou B., Donval J.P., Fifis A., Nadalig T., Cochonat P., Cauquil E., Bourillet J., Moigne J. and Sibuet M., 2005. ROV study of a giant pockmark on the Gabon continental margin. Geo-Marine Letter 25, 281.

Orphan V.J., House C.H., Hinrichs K.-U., McKeegan K.D., Delong E.F., 2001. Methane consuming archaea revealed by directly coupled isotopic and phylogenetic analysis. Science 293, 484-487.

Orphan V.J., House C.H., Hinrichs K.-U., McKeegan K.D., Delong E.F., 2002. Multiple archaeal groups mediate methane oxidation in anoxic cold seep sediments. Proceedings of the national academy of sciences $99,7663-7668$.

Pancost, R.D., Sinninghe Damsté J.S., de Lint S.,. van der Maarel M.J.E.C, Gottschal J.C., 2000. Biomarker evidence for widespread anaerobic methane oxidation in mediterranean sediments by a consortium of methanogenic archae and bacteria. Applied and Environmental Microbiology 66, 1126-1132.

Paull CK., Hecker B., Commeau R., Freeman-Lynde R.P., Neumann C., Corso W.P., Golubic S., Hook J.E., Sikes E., Curray J., 1984. Biological communities at the Florida escarpment resemble hydrothermal vent taxa. Science, 226, 965-967.

Peek AS, Feldman RA, Lutz RA, Vrijenhoek RC (1998) Cospeciation of chemoautotrophic bacteria and deep sea clams. Proceedings of the national academy of sciences 95: 9962 9966.

Reeburgh W.S., 1976. Methane consumption in Cariaco Trench waters and sediments. Earth and Planetary Science Letters 28, 337-349.

Sibuet M., Olu K., 1998. Biogeography, biodiversity and fluid dependence of deep-sea coldseep communities at active and passive margins. Deep-Sea Research II, 45, 517-567.

Thompson J., Higgins D. , Gibson T., 1994 CLUSTAL W : improving the sensitivity of progressive multiple sequence alignment through sequence weighting, position-specific gap penalties and weight matrix choice. Nucleic Acids Research 22: 4673-4680. 
Tunnicliffe V., Juniper S.K., Sibuet M., 2003. Reducing environnements of the deep-sea floor. In: Tyler P.A. (Ed.), Eocsystems of the world : the deep-sea. Elsevier Press, Amsterdam, The Netherlands, pp 81-110.

Treude T., Knittel K., Blumenberg M., Seifert R., Boetius A., 2005. Subsurface microbial methanotrophic mats in the Black Sea. Applied and Environmental Microbiology 71, 63756378.

Valentine, D.L., Reeburgh W. S., 2000. New perspective on anaerobic methane oxidation. Environmental Microbiology 2, 477-484.

Webster G., Newberry C.J, Fry J.C., Weightman A.J., 2003. Assessement of bacterial community structure in the deep sub-seafloor by $16 \mathrm{~S}$ rRNA -based techniques: a cautionary tale. Journal of Microbiological Methods 55, 155-164.

Webster G., Parkes R.J., Fry J.C., Weightman A.J, 2004. Widespread occurrence of a novel division of bacteria identified by $16 \mathrm{~S}$ rRNA gene sequences originally found in deep marine sediments. Applied and Environmental Microbiology 70, 5708-5713.

Webster G., Parkes R.J., Cragg, B.A., Newberry C.J, Weightman A.J, Fry J.C., 2006. Prokaryotic community composition and biogeochemical processes in deep subseafloor sediments from Peru Margin. FEMS Microbiology Ecology, 58, 65-85.

Won Y.-J., Hallam S.J., O'Mullan G.D., Pan I.L., Buck K.R., Vrijenhoek R.C., 2003. Environmental Acquisition of Thiotrophic Endosymbionts by Deep-Sea Mussels of the Genus Bathymodiolus. Applied and Environmental Microbiology 69, 6785-6792.

\section{Figures}

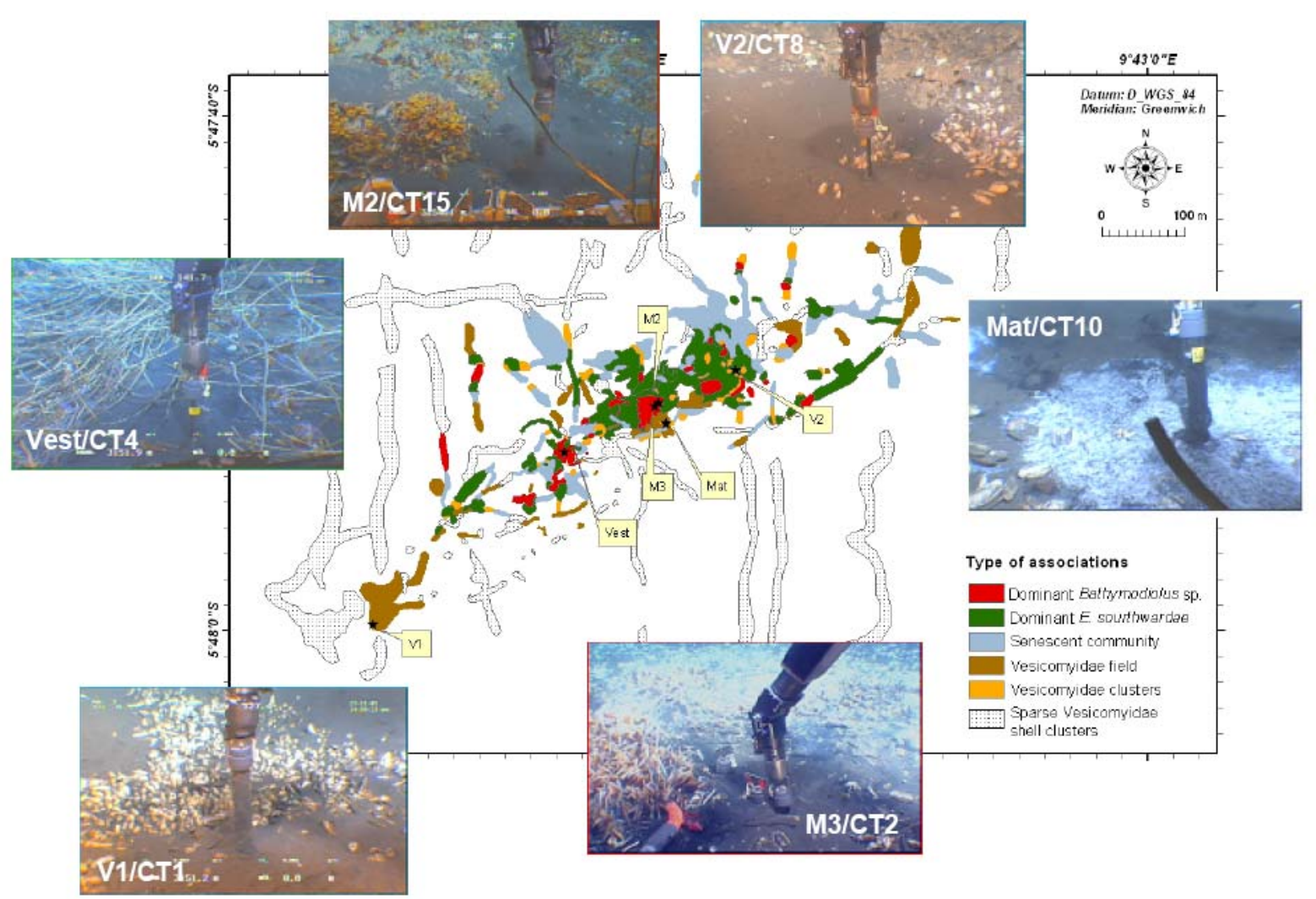


Figure 1 : Map of the REGAB site (adapted from the Olu-Le Roy et al. 2007a) and sediment sampling sites.
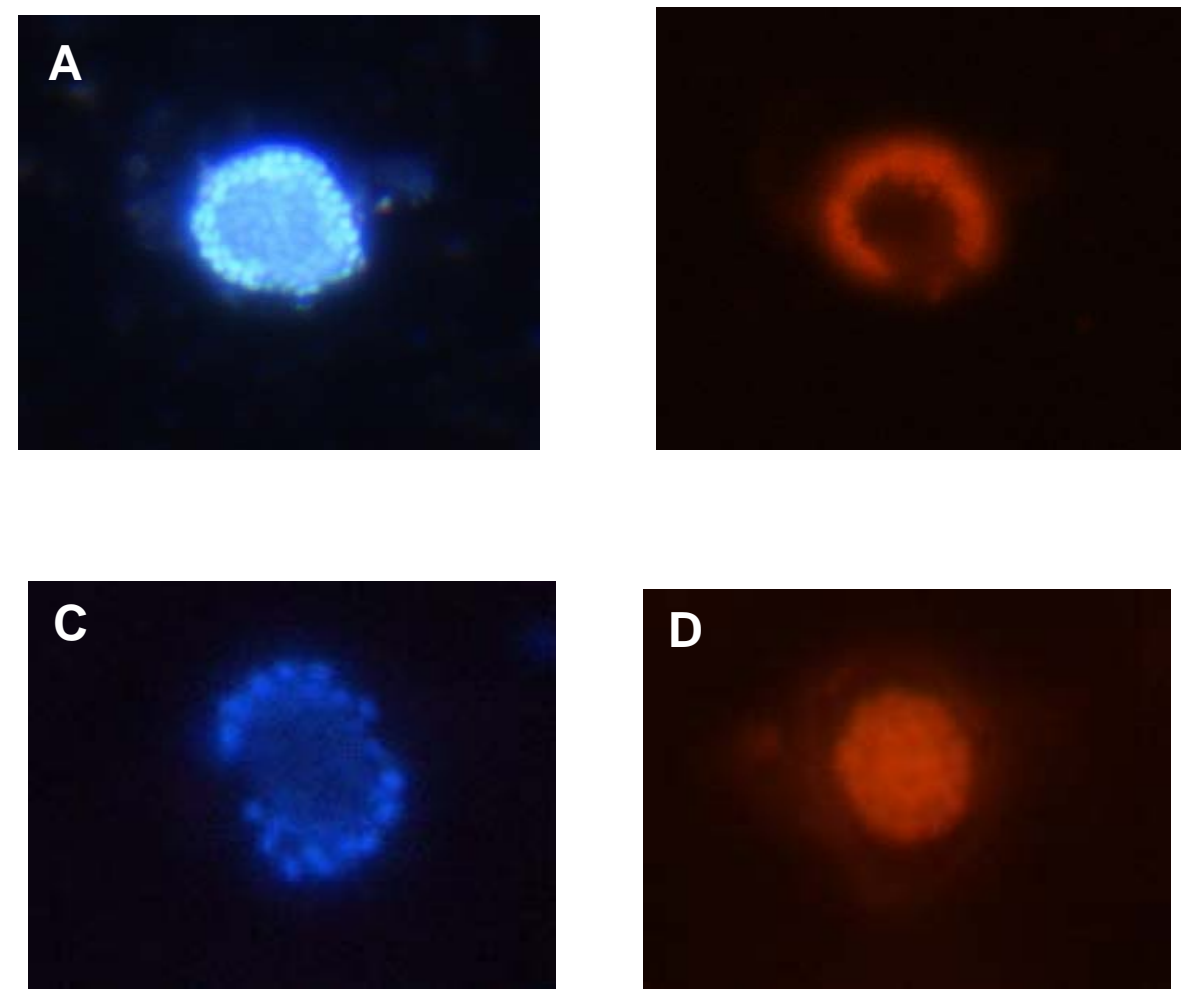

Figure 2 : Consortia of ANME-2 archaea and sulfate-reducing bacteria DSS in sediments of REGAB visualized by fluorescence microscopy and FISH. (A) DAPI staining of aggregate. (B) Corresponding FISH image of same aggregate with probe DSS658 specific for sulfatereducing bacteria (Desulfosarcina /Desulfococcus). (C) DAPI staining of aggregate. (D) Corresponding FISH image of same aggregate with probe EeIMS932 specific for ANME-2 

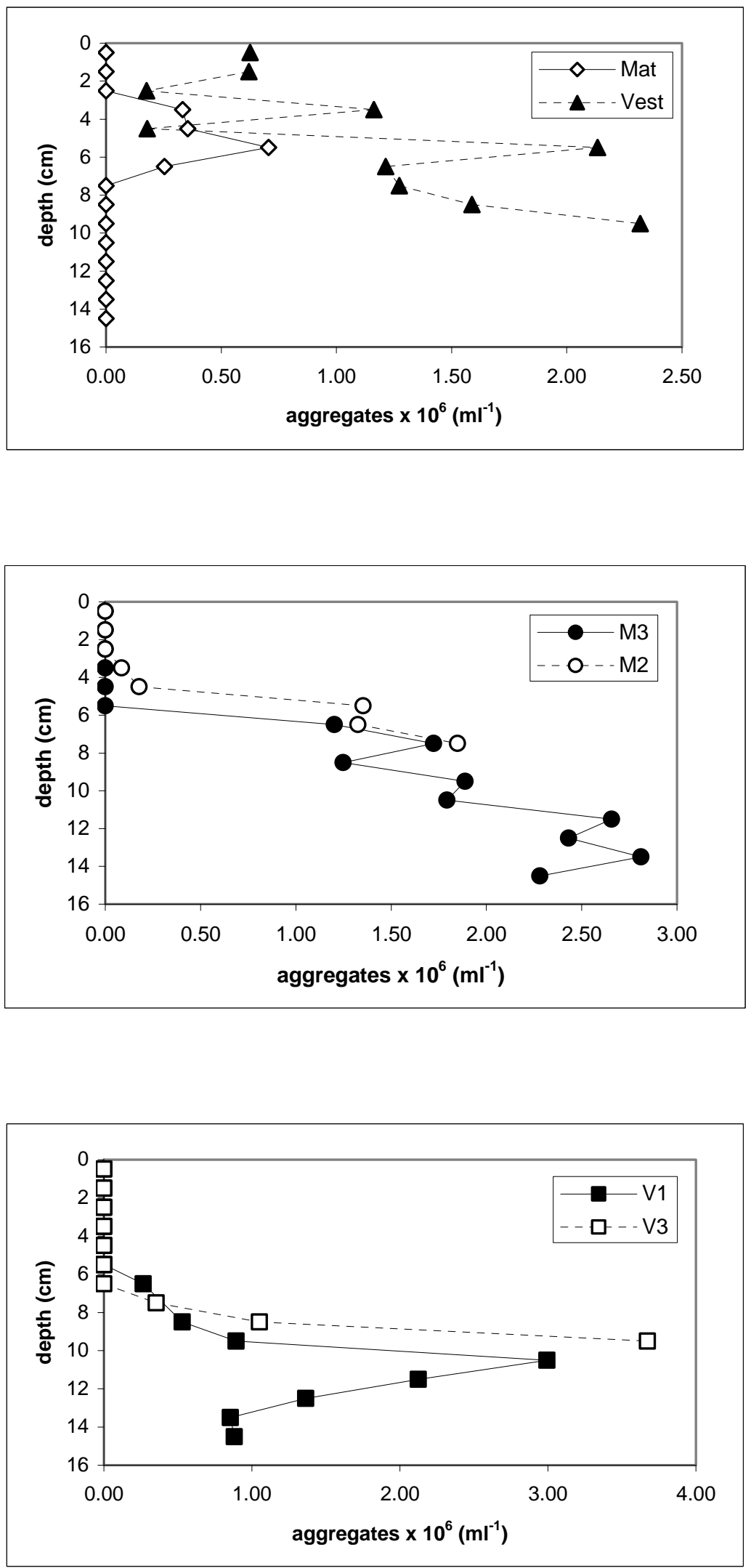

Figure 3 : Detection and quantification of AOM consortia in REGAB sediments by FISH (archaeal probe EelMS932, and bacterial probe DSS658) 


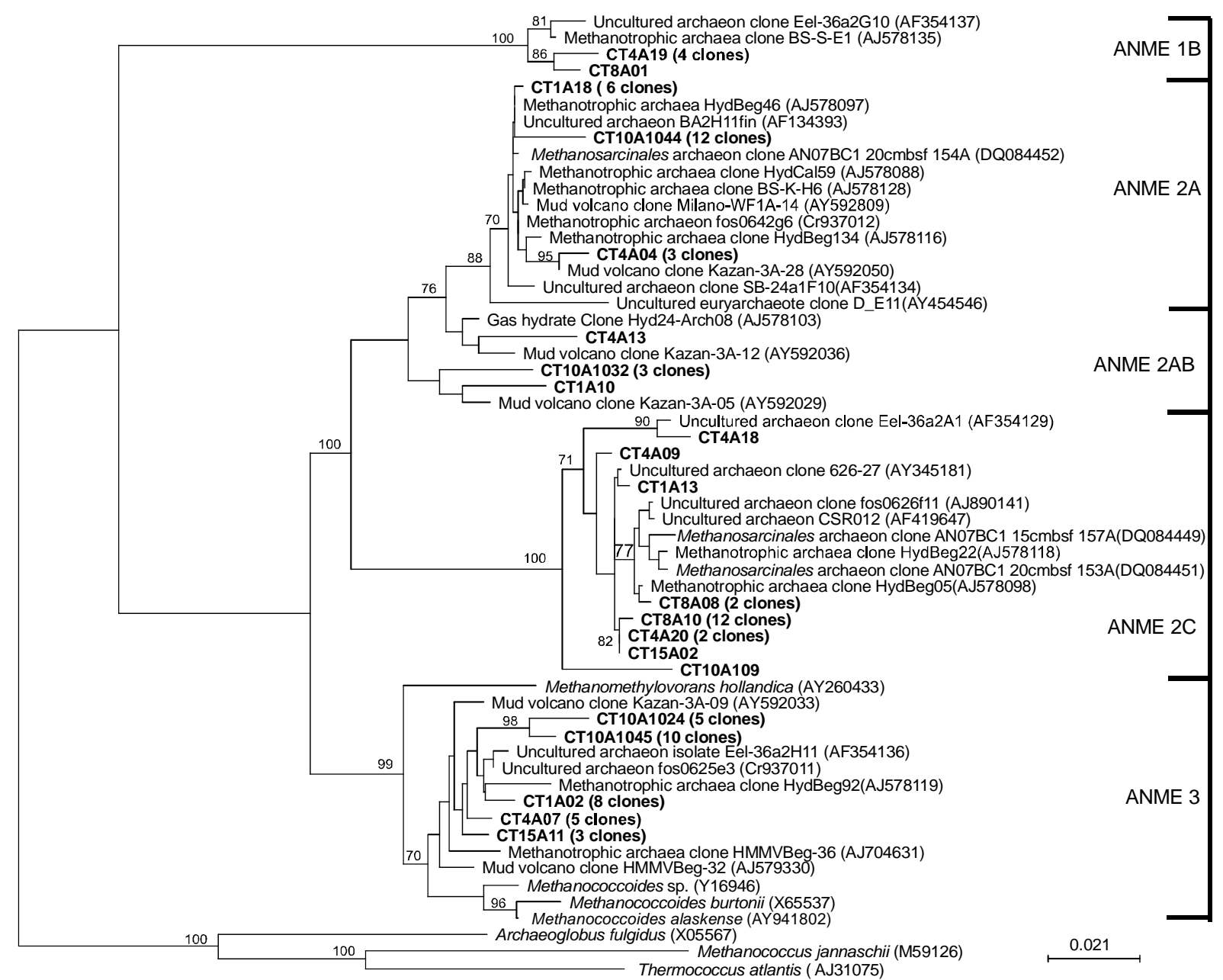

Figure 4 : Phylogenetic trees of Archaea obtained using Neighbour-joining analysis with bootstrap resampling (1000 replicates), based on 558 base pairs. Topologies were confirmed with Maximum Parsimony and Maximum Likelihood. Bootstraps values are indicated on nodes above $70 \%$. The outgroup sequence used was Thermococcus atlantis. 


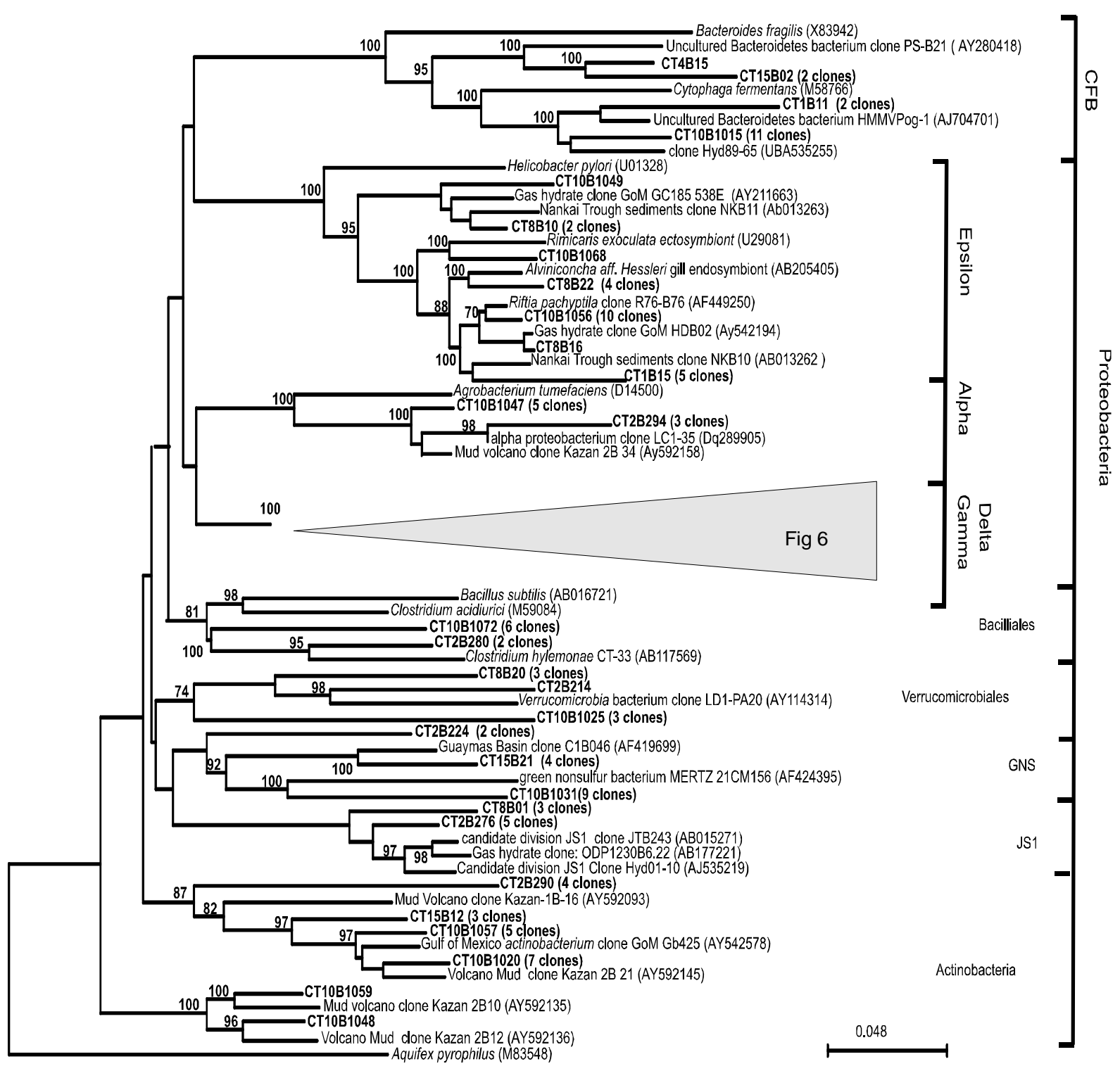

Figure 5: Phylogenetic trees obtained using Neighbor-joining analysis with bootstrap resampling (1000 replicates), based on 812 base pairs. Topologies were confirmed with Maximum Parsimony and Maximum Likelihood. Bootstraps values are indicated on nodes above $70 \%$. The outgroup sequence used was Aquifex pyrophilus. 


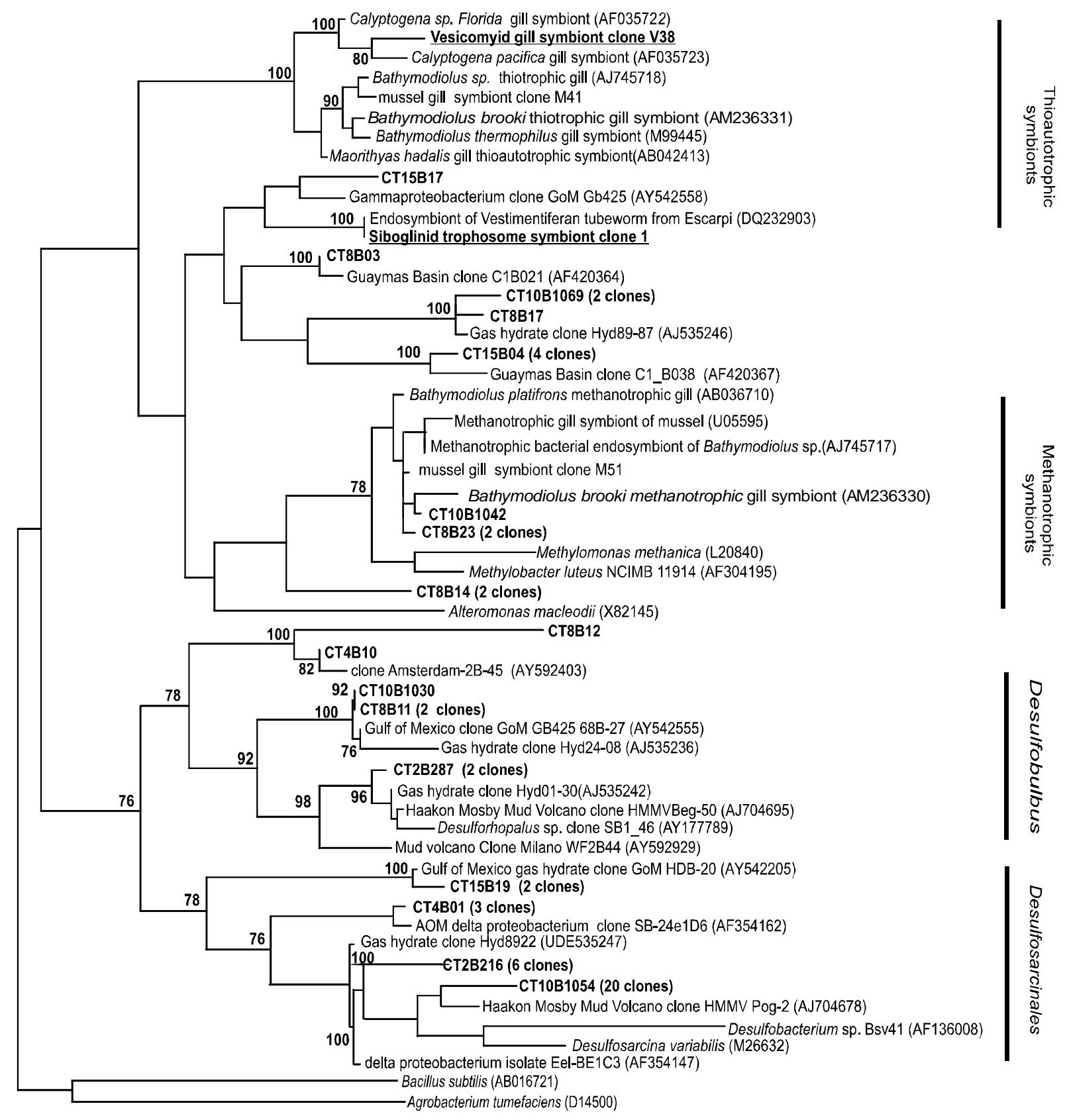

Figure 6 : Phylogenetic trees obtained using Maximum Likelihood analysis with bootstrap resampling (100 replicates), based on 561 base pairs. Bootstraps values are indicated on nodes above $70 \%$. The outgroup sequences used were Agrobacterium tumerfaciens and Bacillus subtilis. 
Table 1: Sampling sites and methane concentrations measured above sediment-water interface. DNA was extracted on sub-sample of each core and the extracted sample is indicated in centimeter below the surface.

\begin{tabular}{ccccc}
\hline $\begin{array}{c}\text { Sampling } \\
\text { site }\end{array}$ & $\begin{array}{c}\text { Sample } \\
\text { name }\end{array}$ & Fauna & $\begin{array}{c}\text { Methane } \\
\text { concentration }(\mu \mathrm{M})\end{array}$ & $\begin{array}{c}\text { DNA } \\
\text { extraction } \\
\mathrm{cm}\end{array}$ \\
\hline M2 & CT15 & Bathymodiolus sp. & 33.7 & $5-8$ \\
M3 & CT2 & Bathymodiolus sp. & 11.8 & $10-15$ \\
V1 & CT1 & Vesicomyidae & 0.9 & $5-10$ \\
V3 & CT8 & Vesicomyidae & 4.4 & $5-10$ \\
Vest & CT4 & Escarpia sp. & 0.7 & $5-10$ \\
Mat & CT10 & Bacterial mat & n. d. & $5-10$ \\
\hline
\end{tabular}

n.d.: not determined

Table 2 : Closest 16S rRNA gene sequence matches to our clone type sequences using the NCBI BLASTN search tool .

\begin{tabular}{|c|c|c|c|c|c|}
\hline $\begin{array}{l}\text { Sample } \\
\text { origin }\end{array}$ & $\begin{array}{l}\text { Sequence } \\
\text { type }\end{array}$ & $\begin{array}{l}\text { Phylogenetic } \\
\text { affiliation }\end{array}$ & $\begin{array}{l}\text { Closest match by BLASTN search } \\
\text { (accession number) }\end{array}$ & $\begin{array}{c}\% \text { of } \\
\text { similarity }\end{array}$ & $\begin{array}{l}\text { Number of } \\
\text { related } \\
\text { clone } \\
\text { (similarity } \\
\text { above } \\
97 \% \text { ) }\end{array}$ \\
\hline $\begin{array}{c}\text { Microbial } \\
\text { Mat (CT10) } \\
\text { Partial } \\
\text { sequences } \\
1000 \text { bp for } \\
\text { bacteria } \\
500 \text { bp for } \\
\text { archaea }\end{array}$ & 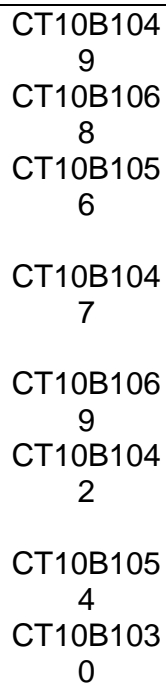 & $\begin{array}{l}\text { Epsilonproteobacteri } \\
\text { a } \\
\text { Alphaproteobacteria } \\
\begin{array}{c}\text { Gammaproteobacter } \\
\text { ia }\end{array} \\
\text { Deltaproteobacteria } \\
\text { CFB } \\
\text { Bacilliales } \\
\text { Verrucomicrobiales }\end{array}$ & $\begin{array}{c}\text { Uncultured clone NKB11 (AB011363) } \\
\text { Uncultured clone C1_B005 (AF420358) } \\
\text { Uncultured clone R76-B76 } \\
\text { (AF449250) } \\
\text { Clone LC1-35 (DQ289905) } \\
\text { Clone Hyd89-87 (AJ535246) } \\
\text { Clone Milano Mud Volcano } \\
\text { (AY592847) } \\
\text { Clone Hyd89-22 (AJ535247) } \\
\text { Clone GoMGC2324463 (AM745212) } \\
\text { Clone HMMVPog-1 (AJ704701) } \\
\text { Clostridium sp. Kas303 (AB114244) } \\
\text { Chlamydial symbiont (EF177461) }\end{array}$ & $\begin{array}{l}98 \\
98 \\
98 \\
99 \\
98 \\
98 \\
98 \\
96 \\
98 \\
98 \\
98 \\
98 \\
98 \\
9\end{array}$ & $\begin{array}{c}1 \\
1 \\
10 \\
5 \\
\\
2 \\
1 \\
20 \\
1 \\
11 \\
6 \\
3 \\
9\end{array}$ \\
\hline
\end{tabular}




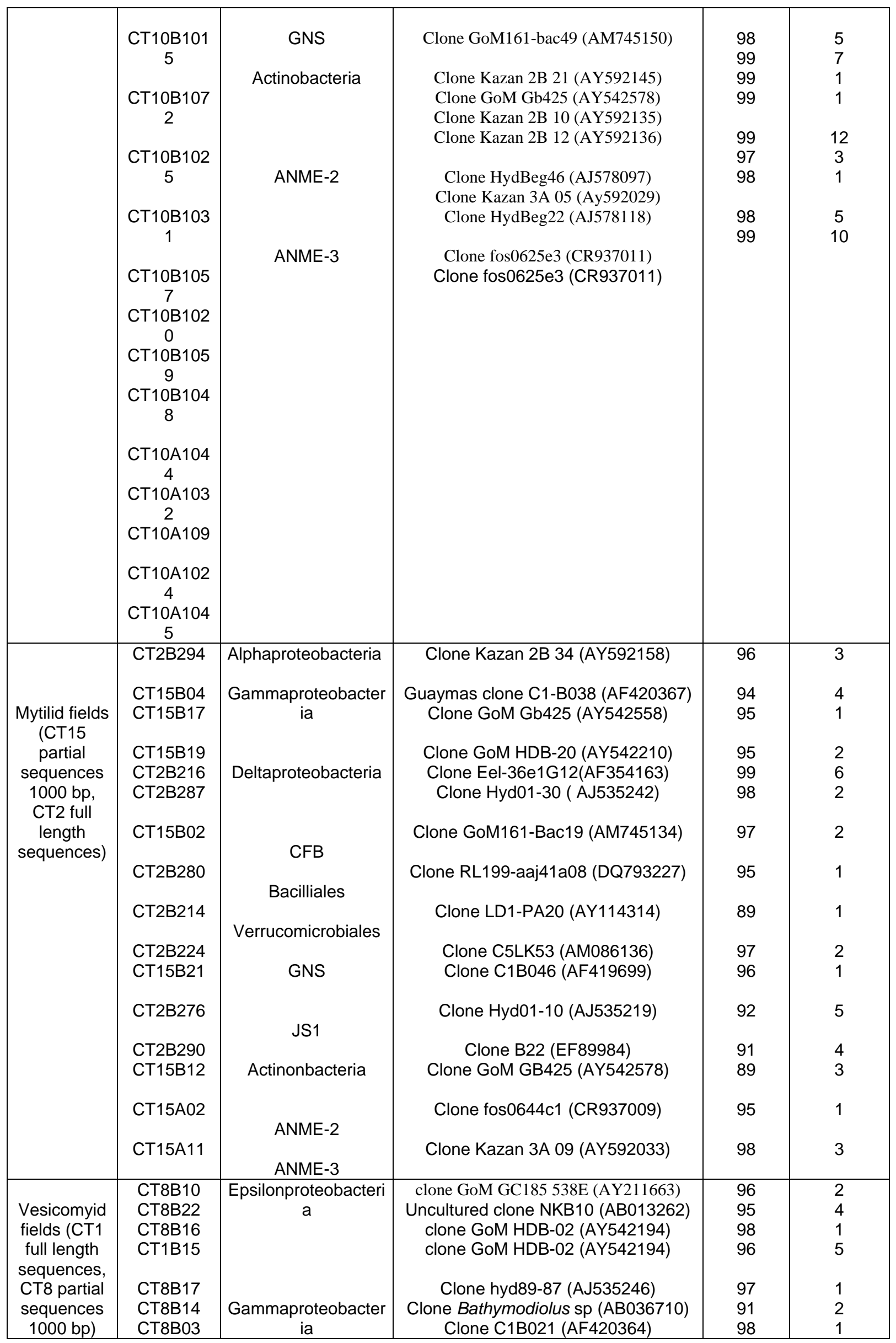




\begin{tabular}{|c|c|c|c|c|c|}
\hline & $\begin{array}{l}\text { CT8B23 } \\
\text { CT8B11 } \\
\text { CT8B12 } \\
\text { CT1B11 } \\
\text { CT8B20 } \\
\text { CT8B01 } \\
\text { CT8A01 } \\
\text { CT1A10 } \\
\text { CT1A13 } \\
\text { CT1A18 } \\
\text { CT8A10 } \\
\text { CT8A08 } \\
\text { CT1A02 }\end{array}$ & $\begin{array}{c}\text { Deltaproteobacteria } \\
\text { CFB } \\
\text { Verrucomicrobiales } \\
\text { JS1 } \\
\text { ANME-1 } \\
\text { ANME-2 } \\
\text { ANME-3 }\end{array}$ & $\begin{array}{l}\text { Clone Bathymodiolus sp (AJ745717) } \\
\text { Clone GoM GB425 (AY542555) } \\
\text { Clone 2B-45 (AY592403) } \\
\text { Clone HMMVPog-1 (AJ704701) } \\
\text { Clone Kazan 3B } 36 \text { (AY592202) } \\
\text { Clone JTB243 (AB015271) } \\
\text { Clone Eel-36a2G10 (AF354137) } \\
\text { Clone Kazan 3A-05 (AY592029) } \\
\text { Clone HydBeg 05 (AJ578098) } \\
\text { Clone fos0642g6 (CR9370012) } \\
\text { Clone AN07BC1 (DQ084451) } \\
\text { Clone AN07BC1 (DQ084451) } \\
\text { Clone fos0625e3 (CR9370011) }\end{array}$ & $\begin{array}{l}98 \\
96 \\
99 \\
\\
97 \\
96 \\
86 \\
\\
98 \\
\\
97 \\
\\
97 \\
97 \\
98 \\
95 \\
96 \\
98\end{array}$ & $\begin{array}{c}1 \\
\\
1 \\
1 \\
8 \\
12 \\
2 \\
\\
8\end{array}$ \\
\hline $\begin{array}{l}\text { Siboglinid } \\
\text { field (CT4, } \\
\text { partial } \\
\text { sequences } \\
1000 \mathrm{bp})\end{array}$ & $\begin{array}{l}\text { CT4B01 } \\
\text { CT4B10 } \\
\text { CT4B15 } \\
\text { CT4A19 } \\
\text { CT4A04 } \\
\text { CT4A13 } \\
\text { CT4A18 } \\
\text { CT4A09 } \\
\text { CT4A20 } \\
\text { CT4A07 }\end{array}$ & $\begin{array}{c}\text { Deltaproteobacteria } \\
\text { CFB } \\
\text { ANME-1 } \\
\text { ANME-2 }\end{array}$ & $\begin{array}{l}\text { Clone SB-24e1D6 (AF354162) } \\
\text { Clone 2B45 (AY592403) } \\
\text { Clone GoM161 B19 (AM745134) } \\
\text { Clone GoM140A80 } \\
\text { Clone fos0642g6 (CR937012) } \\
\text { Clone Kazan 3A-12 (AY592036) } \\
\text { Clone Eel-36a2A1 (AF354129) } \\
\text { Clone fos0644c1 (CR937009) } \\
\text { Clone AN07BC1 (DQ084451) } \\
\text { Clone fos0625e3 (CR9370011) }\end{array}$ & $\begin{array}{l}98 \\
\\
98 \\
94 \\
97 \\
92 \\
98 \\
\\
97\end{array}$ & $\begin{array}{l}3 \\
1 \\
1 \\
1 \\
2\end{array}$ \\
\hline
\end{tabular}

